\title{
Reducing Student Anxiety: The Effects of Collaborative Learning through Computer Conferencing
}

\author{
Michiko Toyama and Kazumasa Mori
}

\begin{abstract}
The purpose of this study is to explore the usefulness of computer conferencing for reducing foreign language anxiety, which could be triggered in foreign language learning and communication. Thirty-five learners of English in Japan participated in three collaborative learning sessions through computer conferencing. To each group, one Filipino teacher and four to five Japanese students were randomly assigned in every session. Before and after the group learning sessions of English, a thirty-nine item questionnaire was administered twice, to assess foreign language anxiety of the participants. Results show that the percentage of respondents who disagreed to anxiety statements increased after the learning sessions. The results of this study suggest that collaborative learning sessions using computer conferencing can be effective in alleviating learners' foreign language anxiety.
\end{abstract}

Index Terms-Anxiety, collaborative learning, computer conferencing, English as a foreign language

\section{INTRODUCTION}

The importance of individual differences has been well known in educational contexts based on the assumption that learning is most efficient when such differences are taken into account. Much of the previous research on individual differences conducted in educational psychology addressed how to adjust instruction to the strengths, weaknesses, and preferences of the learners. Also in second/foreign language (L2) research, individual differences have been examined extensively because there is a wide variation among language learners in terms of their ultimate success in mastering a second or foreign language.

As stated in Dörnyei (2005), personality, ability/aptitude, motivation, learning styles and language learning strategies are core learner variables in L2 studies [1]. In other words, these five variables have generally been seen as the main learner characteristics, which could work as a facilitator or obstructor. Dörnyei points out, however, that there are another five set of variables: anxiety, creativity, willingness to communicate, self-esteem, and learner beliefs. He claims that the latter five variables are important although somewhat underresearched in L2 studies.

Research has shown that anxiety is common in almost all

Manuscript received December 20, 2016; revised February 15, 2017. Thi work was supported in part by the Department of Business Administration of Bunkyo University and by JSPS Grants-in-Aid for Scientific Research Grant Number JP16K01058.

The authors are with Bunkyo University, Kanagawa, Japan (e-mail: toyama3@shonan.bunkyo.ac.jp,morik@shonan.bunkyo.ac.jp). disciplines of learning. Cassady (2010) introduced the term academic anxiety as "a unifying formulation for the collection of anxieties learners experience while in schools" [2]. Although it seems that there are some common features in terms of the nature and consequences of anxiety, "the type of anxiety triggered in and suffered by learners from each specific discipline is, to a certain extent, unique to that specific discipline" [3]. Foreign language anxiety is one such unique type of anxiety. MacIntyre (1999) explains that foreign language anxiety involves the "worry and negative emotional reaction aroused when learning or using a second language" [4].

A large number of studies have investigated the relationship between foreign language anxiety and L2 achievement. These studies generally report a consistent moderate negative relationship between measures of language anxiety and language achievement [5].

Although there is no doubt that anxiety affects L2 performance, its nature and impacts on L2 learning and communication is not fully understood. Besides, even if a great deal of effort has been made in the literature to develop methods to reduce anxiety, very little is known about the use of collaborative learning through computer conferencing in L2 classrooms to reduce foreign language anxiety. Collaborative learning can play an important role in addressing the issue of anxiety. In addition, facing a foreign teacher through skype could be not only encouraging for students to engage in English conversations but also helpful in building confidence and reducing various types of anxieties.

\section{The PILOT STUdY}

To investigate the usefulness of collaborative learning through computer conferencing for reducing foreign language anxiety, a pilot study was conducted [6]. The participants were thirteen undergraduate students in Japan. Data were collected using a questionnaire consisting thirty-nine items for assessing English as a foreign language (EFL) anxiety. The questionnaire was administered before and after three group learning sessions with Filipino instructors using Skype. Results show that the participants' anxiety was significantly reduced after the collaborative learning sessions. An implication of this pilot study is the possibility that collaborative learning with a foreign teacher using computer conferencing can alleviate foreign language anxiety.

\section{Purpose OF THE Study}

The current study therefore set out to advance the pilot 
study described above. By increasing the number of participants, we can collect and analyze more data to deepen our understanding of foreign language anxiety.

This paper attempts to explore the usefulness of collaborative learning through computer conferencing for reducing anxiety involving the worry and negative emotional reaction aroused in learning or using a foreign language. Data for this study were collected twice, before and after three group learning sessions through computer conferencing, using a questionnaire. The data were analyzed to see if anxiety of the participants of this study was reduced after the learning sessions. The results of data analysis will be described and the suggestions for EFL classrooms will be made in this paper.

\section{MEthods}

\section{A. Participants}

Thirty-five undergraduates of business major at a university in Japan participated in this study. The sample consisted of twenty-four male and eleven female students. The participants' age ranged from 18-20 years. They did not receive any compensation for participating this research. They all study English as a foreign language (EFL) at the university.

\section{B. Anxiety Scale}

The discussions and analyses of foreign language anxiety emerged during the 1960s. The Foreign Language Classroom Anxiety Scale (FLCAS) devised by Horwitz (1986) marked the beginning of systematic research on L2 learners' anxiety [7]. Many researchers devised instruments to measure anxiety triggered in L2 learning or communication. In Japan, Motoda (2000) devised Japanese Language Anxiety Scale (JLAS) for learners of Japanese language [8]. Her scale was based on Horwitz's FLCAS, Gardner (1985), Ely (1986), MacIntyre \& Gardner (1988), Young (1990), Ehrman \& Oxford (1991), and MacIntyre \& Gardner (1994)'s scales [9]-[14]. Note that her scale was intended to measure L2 speaking anxiety.

The instrument in this study includes thirty-nine items of Motoda's JLAS and 5-point Likert type scale, which ranges from "Strongly agree" to "Strongly disagree." The first twenty-three items shown in Table I measure self-reports regarding in-class anxiety. The latter sixteen items shown in Table II measure self-reports regarding out-of-class anxiety. The respondents' anxiety levels can be measured by adding up the ratings of these items. Since all the items in JLAS were written in Japanese, they were translated into English by the authors for reference in this paper. Also, some items originally contained the word "Japanese" since JLAS was intended for learners of Japanese. For instance, there were items such as I get nervous when I am speaking Japanese in class. Therefore, the word "Japanese" was changed to "English" in each statement as the present instrument is intended for learners of English. The participants were asked to read each statement and then to indicate a response ranging from 1 = "Strongly disagree" to $5=$ "Strongly agree". All the items and response options for the questionnaire were written in Japanese to avoid any problems Japanese learners could encounter understanding the items and response options.

TABLE I: The ENGLISH LANGUAGE IN-Class SPEAKING ANXIETy SCALE

1. I feel anxious when I know that I'm going to be called on.

2. I get nervous when I am speaking English in class.

3. I get nervous when I am giving a presentation in English in class.

4. I get nervous when I am reading aloud in English in class.

5. In class, I worry about making mistakes.

6. When I get nervous in my English class, I forget English words I know.

7. I get nervous when I am discussing something in English in class.

8. I get nervous when I am role-playing in English in front of my class.

9. I get nervous when a teacher asks me to answer a question.

10. I get nervous when I find what is being taught in my English class difficult.

11 I get nervous when a teacher is speaking fast in English.

12. I get nervous when English classes are move so quickly and I am getting left behind.

13. I get nervous when audio or visual learning materials are too fast for me to follow.

14. I get nervous when a teacher doesn't understand what I'm saying in English.

15. I get nervous when I don't understand what is being said in English in recordings.

16. I get nervous when I don't know how to answer my teacher's questions.

17. I get nervous when I have to study a lot in English classes.

18. I am afraid that other students will laugh at me when I speak English.

19. I am afraid that other students will think that I am bad at English.

20. I feel embarrassed when I make errors in English in front of other students.

21. I am afraid that my English proficiency level is lower than other students.

22. I am afraid that I am not able to learn English in class.

23. I am afraid that my teacher will scold me if I make errors in English.

\section{Group Learning through Computer Conferencing}

Three group learning sessions were conducted using computer conferencing. Each session lasted for twenty-five minutes and was separated from the next session by six days. To each group, one Filipino teacher and four or five Japanese students were randomly assigned in every session. Each student used a headset, a computer, a monitor and skype to learn and practice English in groups. The computer conferencing service, teaching materials and Filipino instructors were provided by QQ English, Co. Ltd.

There were three teaching topics prepared for the participants: body pains, daily routines and food. Every session starts with a warm-up task where students looked at some pictures and describe them in English using the vocabulary words provided by instructors. Then, the instructors introduced key grammatical structures such as "I feel great." and "I have a toothache." Then, a controlled conversational practice, a role-playing, and 4-skills integrated exercises follow.

The participants were provided with a list of useful English expressions for group learning to encourage them to communicate in English and to help them overcome possible conversational obstacles. The followings are the examples of the expressions provided to the participants.

At the beginning of class

- Hi. 
- How are you? / How're you doing?

- Good. Thanks. And you?

During class

- Once more, please.

- Excuse me?

- Slowly, please.

- Could you speak slowly?

- I can't hear you.

- Could you speak louder?

- What does it mean?

- What does ... mean?

- How do you spell it?

- I think so, too.

- I don't understand.

- I don't know.

- Is it my turn?

At the end of class

- Thank you. See you.

TABLE II: THE ENGLISH LANGUAGE OUT-OF-ClASS SPEAKING ANXIETY SCALE

24.I get impatient when English speakers (teachers and foreigners) do not understand my English after repeating a few times.

25.I get worried when I am talking with an English speaker (teachers and foreigners) and cannot express myself in English well.

26.I get worried when an English speaker (teachers and foreigners) is listening to me with confusion in their faces.

27.I get worried when an English speaker (teachers and foreigners) is listening to me and asking for repetition.

28.I get worried when I don't understand what an English speaker (teachers and foreigners) is saying and don't know how to respond.

29.I get impatient when I am talking with English speakers (teachers and foreigners) and forget the English words that I know.

30.I am afraid that I will not be able to speak English well when I meet someone for the first time.

31.I get worried when English speakers (teachers and foreigners) use English expressions or structures that are different from the ones I leaned in class.

32.I am afraid that I will not make errors in English when I talk with English speakers (teachers and foreigners).

33.I am afraid that I am not be able to have a conversation in English.

34.I am afraid that English speakers (teachers and foreigners) will laugh at my English.

35. When I talk with English speakers (teachers and foreigners), I get nervous because I think that I have to speak English quickly.

36.I am afraid that English speakers (teachers and foreigners) will think that I am bad at English.

37.I get nervous and cannot speak English when I am with someone who speaks better English than I do.

38.I am afraid that I will not be able to talk with my teacher in good English when I am out of class.

39.I am afraid that I don't make any progress in English.

\section{Data Analysis}

A combination of quantitative and qualitative approaches was used in the data analysis. Data analysis was conducted with respect to the objective set for this study. All analysis was carried out using $\mathrm{R}$ version 3.3.

\section{RESULTS AND DISCUSSIONS}

\section{A. Comparison of Pre-assessment and Post Assessment}

As the sample size was not large in this study, the generalizability of the results is subject to certain limitations. Having said that, it is important to note that the rate of participants who selected "disagree" or "strongly disagree" for the items shown in Table I and Table II increased after the group learning sessions. Therefore, it is suggested that group learning sessions using computer conferencing in an EFL context can be effective in alleviating learners' foreign language speaking anxiety.

Table III provides the results obtained from frequency analyses of English language speaking anxiety items. Note that this table shows the results of all thirty-nine items in the current instrument. Closer inspection of the table shows that the percentage of the participants who reported to be "not anxious", in other words, those who selected "disagree" or "strongly disagree", increased from $20.8 \%$ to $23.0 \%$. It should be noted that the difference between pre-assessment and post-assessment shown in Table III was statistically significant $\left(\chi^{2}(4)=11.70, p\right.$-value $\left.=0.02\right)$.

TABLE III: FREQUENCY ANALYSES OF ENGLISH LANGUAGE SPEAKING ANXIETY ITEMS

\begin{tabular}{l|r|r|r|r|r}
\hline \hline \multicolumn{7}{c}{$\begin{array}{l}\text { strongly } \\
\text { agree }\end{array}$} & \multicolumn{1}{l}{ agree } & neutral & disagree & $\begin{array}{l}\text { strongly } \\
\text { disagree }\end{array}$ \\
\hline Pre & $14.5 \%$ & $48.5 \%$ & $16.2 \%$ & $14.7 \%$ & $6.1 \%$ \\
\cline { 2 - 6 } Post & $14.5 \%$ & $50.3 \%$ & $12.2 \%$ & $14.9 \%$ & $8.1 \%$ \\
\hline \hline
\end{tabular}

Interestingly, no decrease in the mean anxiety scores was detected. The mean anxiety score for the pre-assessment was 136.69 and for the post-assessment was 137.63. This finding was unexpected as it disagrees with the results of the pilot study described above.

A possible explanation for this result might be that the groups in the current study were bigger than the ones in the pilot study. As described above, four or five students and one teacher were assigned to each group in this study whereas only two or three students and a teacher were assigned to each group in the pilot study. Japanese students are commonly considered shy and reticent; therefore, the smaller groups for collaborative learning could be more effective in reducing anxiety.

Another possible explanation for this may be related to mixed proficiency group. In the pilot study, there were only thirteen participants and all students were low-leveled. In this study, however, mixed proficiency groups were made randomly for collaborative learning. It can therefore be assumed that collaborative learning can be more helpful for EFL learners in reducing anxiety when group members have the same proficiency.

This assumption can be supported by the psychological status of foreign language learners. As indicated in the questionnaire items in Table I, a foreign language learner is likely to be afraid that other students will think that (s)he is bad at English. (S)he is likely to be afraid that other students will laugh at him or her when (s)he speaks English. (S)he may be afraid that his or her English proficiency level is lower than other students. Moreover, foreign language learners are highly likely to feel embarrassed when they make errors in English in front of other students. In addition, they may get nervous and become unable to speak English when they are with someone who speaks better English than they 
do. Considering such sensitive psychological status of foreign language learners, it is possible to hypothesize that a group of students with the same proficiency level is better for reducing anxiety.

Taken all together, it is suggested that collaborative learning through computer conferencing can be more effective with small groups. A group with two or three students of the same proficiency and one teacher may be an ideal setting for learning English as a foreign language since it can provide students with relaxing and comfortable atmosphere and more help to alleviate anxiety.

\section{B. Comparison with Motoda's Study}

In this section, foreign language anxiety of the Japanese EFL learners in this study and non-Japanese learners of Japanese in Motoda's (2000) study will be compared. Motoda reported that the mean score for in-class anxiety of non-Japanese learners was 77.97. On the other hand, the mean score of Japanese learners in this study was 80.34 in pre-assessment and 81.03 in post-assessment. Therefore, it is suggested that Japanese EFL learners are more likely to get nervous, tense, worried, or impatient when they speak or try to understand their target language in class.

\section{CONCLUSION}

The goal of this paper was to investigate the usefulness of collaborative learning through computer conferencing for reducing anxiety involving the worry and negative emotional reaction aroused in learning or using a foreign language. The results of the pre-assessment and post-assessment of foreign language anxiety were analyzed and the following results were obtained:

1) The percentage of the participants who reported to be "not anxious", in other words, those who selected "disagree" or "strongly disagree" for the questionnaire items, increased from $20.8 \%$ to $23.0 \%$.

2) No decrease in the mean anxiety scores was detected. In fact, it slightly increased from 136.69 to 137.63 ; however, the difference was not significant.

3) This unexpected results may be related to the size and mixed proficiency of the groups for collaborative learning through computer conferencing. A group with two or three students of the same proficiency and one teacher may be an ideal setting for Japanese EFL learners to alleviate their foreign language anxiety.

4) Compared with non-Japanese L2 learners, Japanese EFL learners showed higher level of in-class anxiety. Thus, it is suggested that Japanese EFL learners are more likely to get nervous, tense, worried, or impatient when they speak or try to understand their target language in class.

Overall, this study deepen our understanding of foreign language. An implication of this study is the possibility that L2 learners can be less anxious and more successful by experiencing collaborative learning with a foreign teacher using computer conferencing. There are, however, still many unanswered questions about foreign language anxiety. Further work should be undertaken to investigate the usefulness of collaborative learning and computer conferencing with the target language speakers for the purpose of reducing foreign language anxiety.

\section{REFERENCES}

[1] Z. Dörnyei, The Psychology of the Language Learner: Individual Differences in Second Language Acquisition, Mahwah, NJ: Lawrence Erlbaum, 2005.

[2] J. C. Cassady, Anxiety in Schools: The Causes, Consequences, and Solutions for Academic Anxieties, vol. 2, Peter Lang, 2010.

[3] T. T. T. Trang, "A review of Horwitz, Horwitz and cope's theory of foreign language anxiety and the challenges to the theory," English Language Teaching, vol. 5, no. 1, pp. 69-75, 2012.

[4] P. D. MacIntyre, "Language anxiety: A review of the research for language teachers. In: YOUNG, D. J. (Ed.)," Affect in Foreign Language and Second Language Learning: A Practical Guide to Creating a Low-Anxiety Classroom Atmosphere, Boston: McGraw-Hill, 1999, pp. 24-45.

[5] E. Horwitz, "Language anxiety and achievement," Annual Review of Applied Linguistics, vol. 21, pp. 112-126, 2001.

[6] T. Mori and Shintani, "Using computer conferencing to improve speaking skills and affective factors of EFL learners: A pilot study for remedial education of English," LET Kanto Journal, 2017.

[7] E. K. Horwitz, M. B. Horwitz, and J. Cope, "Foreign language classroom anxiety," The Modern Language Journal, vol. 70, no. 2, pp. 125-132, 1986.

[8] S. Motoda, "Measurement of second language anxiety in the target language environment: The Japanese language anxiety scale — Test construction, reliability, and validity," Japanese Journal of Educational Psychology, vol. 48, no. 4, pp. 422-432, 2000.

[9] R. C. Gardner, Social Psychology and Second Language Learning: The Role of Attitudes and Motivation, London: Edward Arnold, 1985.

[10] C. M. Ely, "An analysis of discomfort, risktaking, sociability, and motivation in the L2 classroom," Language learning, vol.36, no. 1, pp. 1-25, 1986.

[11] P. D. MacIntyre and R.C. Gardner, The Measurement of Anxiety and Applications to Second Language Learning: An Annotated Bibliography, London, Ontario: The University of Western Ontario, Department of Psychology.

[12] D. J. Young, "An investigation of students' perspectives on anxiety and speaking," Foreign Language Annals, vol. 23, no. 6, pp. 539-553, 1990.

[13] M. E. Ehrman and R. L. Oxford, “Affective survey," 1991.

[14] P. D. MacIntyre and R. C. Gardner, "The subtle effects of language anxiety on cognitive processing in the second language," Language Learning, vol. 44, no. 2, pp. 283-305, 1994.

Michiko Toyama was born in Yokohama, Japan. She received her Ph. D degree in linguistics from Sophia University in Tokyo, Japan. Her research interests include computer-assisted language learning, affective learner variables, English as a foreign language education, intercultural communication, and applied phonetics.

She is an assistant professor of English at Bunkyo University, Japan. She was an instructor at Sophia University. She is currently involved in the research projects on: 1) Using computer conferencing in EFL education, 2) motivation and self-efficacy in intercultural communication and EFL education, and 3) perception and production of L2 English intonation.

Kazumasa Mori was born in Nagoya, Japan. He received his Ph. D. degree in educational statistics from the University of Tokyo in Japan. His research interests include computer-assisted assessment in education and educational measurement.

$\mathrm{He}$ is an associate professor of statistics at Bunkyo University, Japan. He was an assistant professor at Tokyo University. He is currently involved in the research projects on: 1) Using computer conferencing in EFL education, 2) improvement of statistical models for educational measurement and 3) developing assessment system for undergraduate admissions. 